\title{
The Effect of Early Winter or Spring Burning on Runoff, Sediment, and Vegetation in the Post Oak Savannah of Texas
}

\author{
N.E. GARZA, JR., AND W.H. BLACKBURN
}

\begin{abstract}
A replicated small plot $(1.8 \mathrm{~m} \times 22.1 \mathrm{~m})$ study was conducted on the Texas A\&M University Native Plant and Animal Conservancy in Brazos County, Texas. The purposes of the study were to determine the effects of seasonal burning on runoff and sediment loss and to describe vegetal differences resulting from the burning treatments. A grass-dominated community and a brush-dominated community were studied. Mean runoff from both communities tended to be greater from unburned plots than from burned plots although differences were seldom significant. Mean sediment export (kg/ha) was similar from the treatments during the 15 month study. However, nonsignificant trends suggested that plots burned in the spring lost less sediment than did unburned plots or those burned in early winter. Most sediment loss occurred during June, September, and November as a result of highly intense thunderstorms. Burning did not adversely affect runoff or sediment. Changes in vegetative composition and vigor did occur and these changes appeared to be compatible with most management objectives. Percent foliar cover of live vegetation was greater on burned than unburned plots; however, total foliar cover was greatest on unburned plots. Burning in early winter favored growth of forbs, whereas spring burning tended to favor the production of grasses.
\end{abstract}

The use of fire as a natural resource management tool has undergone a significant revival in the past 2 decades (Scifres 1980). Undisturbed native rangelands have developed through a combination of climatic, biologic, and edaphic factors. Historically, fire is believed to have shaped and maintained our native grasslands and prairie savannahs (Sauer 1950, Scifres 1980, Shantz 1947).

Sheet erosion is reduced by a cover of herbaceous vegetation or mulch material, which acts to dissipate raindrop energy before damage is done to the soil (Brady 1974). Raindrops are capable of moving large amounts of soil short distances if the surface is not covered with vegetation or mulch. Areas denuded by fire are exposed to potentially high rates of erosion by water. Removal of mulch and herbaceous vegetation by burning can affect the quality and quantity of runoff.

The impact of raindrops can lead to a breakdown of soil aggregates when vegetation and mulch cover are removed, especially from fine textured soils. This results in surface sealing and reduced infiltration which can be accentuated on burned sites by the breakdown of organic matter, structure and aggregates in the soil surface. The effectiveness of plant cover in reducing sheet erosion and increasing infiltration rates is directly proportional to the amount of cover present (Osborn 1954, Blackburn 1975). Crusting may occur when the soil surface dries, further reducing infiltration and sometimes restricting plant growth (Spurr and Barnes 1973, Brady 1974).

\footnotetext{
Authors are research associate, Texas Agricultural Experiment Station, Sonora. Texas 76950; and professor of watershed management, Range Science Department, Texas A\&M University, College Station, Texas 77843. At the time of the research the senior author was research assistant, Range Science Department, Texas A\&M University.

This article is published with the approval of Director, Texas Agricultural Experiment Station, as TA 19331.

Manuscript accepted October 15, 1984
}

Stoddart et al. (1975) generalized that forage yield is usually less after burning and Trlica and Schuster (1969) found decreases of 15 to $35 \%$ on burned areas in the Texas High Plains. Conversely, Wright (1974) found under favorable moisture conditions that herbage yields were increased $41 \%$ by burning; and, in a year receiving less than half the normal rainfall, herbage yields were $13 \%$ greater than on adjacent unburned areas. The timing and amount of moisture received after burning seems to be a critical factor affecting herbaceous plant performance. Post-burn production can also fluctuate with season of burn (McMurphy and Anderson 1965). Spring burning appears to be least harmful to subsequent production (Stoddart et al. 1975).

These potential changes in the vegetative structure of an area from prescribed burning raise the question of how much stress in terms of erosion can be allowed on an area to achieve the most benefit from the site without causing irreparable damage. The objectives of this study were to determine the effects of seasonal burning on surface runoff and sediment loss and to describe vegetal differences resulting from the burning treatments.

\section{Study Area}

The study site is located on the Texas A\&M Native Plant and Animal Conservancy, $5 \mathrm{~km}$ west of College Station in Brazos County, Texas. Brazos County lies within the Post Oak Savannah which Gould (1975) refers to as an extension of the oak-hickory forest. It is an ill-defined area between the Pineywoods on the east and the Cross Timbers and prairies on the west, and is intermingled with portions of the Blackland Prairie.

The climate is subhumid with a mean annual rainfall of $98 \mathrm{~cm}$. Mean temperatures range from $9.5^{\circ} \mathrm{C}$ in January to $29.5^{\circ} \mathrm{C}$ in July and the relative humidity averages $71 \%$ (Griffiths and Strauss 1981). Soils of the county generally consist of a fine sandy loam or calcareous clay A horizon with a claypan B horizon. The soil's shrink/swell potential is high, water penetration is slow and root growth is generally restricted.

The plant communities chosen for study were a brownseed paspalum (Paspalum plicatulum)/little bluestem (Schizachyrium scoparium) community and a post oak (Quercus stellata)/yaupon (Ilex vomitoria)/brownseed paspalum community. Community selection was based on homogeneity of soils and topography. Soils of the study area are of the Tabor series, a fine, montmorillonitic, thermic Udertic Paleustalf. The soils of brush-dominated community are characterized by $20 \mathrm{~cm}$ of acid fine sandy loam over a layer of acidic red clay. The grass community soils have been so severely eroded that the acid fine sandy loam surface horizon has been removed, leaving the heavy "claypan" exposed. Domestic grazing animals have been excluded from the site for at least 20 years.

Scheduled burns for this project were initiated on 12 December 1980, 8 March 1981, 22 December 1981, and I March 1982. Hereafter, the December burns initiated after the growing season will be referred to as early winter burns and the March burns initiated just prior to spring green up as spring burns. The 1980 early winter burn 
was conducted under broken to scattered clouds and an air temperature of about $18^{\circ} \mathrm{C}$. Relative humidity varied from $49 \%$ at 1200 hours to $53 \%$ at 1700 hours, and the wind was from the south at 12 to $14 \mathrm{~km} / \mathrm{h}$. Similar conditions occurred during the spring burn with scattered clouds, $17^{\circ} \mathrm{C}$, and wind from the northnorthwest at 5 to $14 \mathrm{~km} / \mathrm{h}$. Relative humidity was $60 \%$ at 1200 hours but was $52 \%$ by 1700 hours. The early winter 1981 burn was initiated under clear to partly cloudy skies with an air temperature of $27^{\circ} \mathrm{C}$ at 1300 hours dropping to $20^{\circ} \mathrm{C}$ by 1700 hours. Wind was blowing from the north-northwest at $22 \mathrm{~km} / \mathrm{h}$ and gusty. The relative humidity was $57 \%$ at 1200 hours and $20 \%$ by 1700 hours. The spring burn was conducted under clear skies, $22^{\circ} \mathrm{C}$, a relative humidity of about $32 \%$, and wind from the north at 0 to $11 \mathrm{~km} / \mathrm{h}$.

\section{Methods}

Twelve permanent runoff plots $1.8 \mathrm{~m} \times 22.1 \mathrm{~m}(0.004 \mathrm{ha})$ were established within each community. The 24 plots were arranged in a split-plot design. Plots within communities were divided into 4 groups of 3 based upon similarity of soils, topography, and vegetation. The plots within these $\mathbf{4}$ groups were then randomly assigned 1 of 3 treatments: unburned, early winter burned or spring burned. Burning treatments for each season were applied to 4 grass plots and 4 brush plots.

Each 0.004 -ha runoff plot was delineated by placing fiberglass strips along its top boundary and 2 long sides. The lower end was fitted with a fiberglass trough to catch and funnel runoff through a splitting device into a 120-liter plastic container. Splitters were calibrated using a known quantity of water at a uniform flow rate and were kept in a horizontal position with a bubble level. Plot slope ranged from 3.0 to $6.2 \%$.

Runoff was measured after each rainfall event and collected water was agitated with a 12-volt pump to thoroughly mix sediment and debris. Water subsamples were collected in a 1-liter plastic bottle for sediment determination. The sediment from each subsample was filtered through a \#1 Whatman filter, dried at $105^{\circ} \mathrm{C}$ for $24 \mathrm{hrs}$, weighed, and converted to sediment loss in $\mathrm{kg} / \mathrm{ha}$. The barrels were pumped dry after each collection and made ready for the next runoff event.

Placement of rain gages allowed for complete coverage of the 2 study sites. Centrally located between each plant community was 1 standard $26-\mathrm{cm}$ rain gage and 1 standard recording rain gage. At opposing ends of each community a $26-\mathrm{cm}$, standard rain gage was installed. This arrangement allowed for a measurement of total rainfall and a record of the storm intensity and duration.

Rainfall events were grouped into wet or dry seasons. The wet season began on November 1 and ended on May 31. The dry season began on June 1 and ended on October 31. Storms were grouped into 9 categories by total amount of precipitation and the 5-day antecedent moisture level (Soil Conservation Service 1964). Because of the high eva potranspiration demand during the summer, greater precipitation and 5-day antecedent moisture values were used for the dry season than for the wet season. The levels were consolidated further into 6 moisture condition classes because of missing values attributed to the sporadic nature of the natural runoff (Table 1).

Herbaceous vegetation was sampled using a 20-point frame (Mueller-Dombois and Ellenberg 1974). One hundred foliar hits and 100 basal hits were taken from each plot on 31 January, 21 April, 18 August, and 19 December 1981; 16 March and 5 August 1982. The points were taken from 5 permanent stations, placed equidistant along the length of the plot. Plants encountered were divided into 3 categories: live forbs, or grass, or standing dead material.

Canopy cover of woody vegetation on the brush community was estimated in August 1981 and 1982 using a modification of the line intercept method (Mueller-Dombois and Ellenberg 1974). Eleven 1.8-m lines were placed across each plot. Lines were equidistant from each other and from the ends of the plot. Cover values were able 1. Six moisture condition classes for the wet (1 Nov. through 31 May) and dry (1 June through 31 Oct.) seasons antecedent moisture and total precipitation used in analysis of storm-flow from runoff plots, Post Oak Savannah, Texas.

\begin{tabular}{lccc}
\hline \hline $\begin{array}{l}\text { Moisture } \\
\text { condition } \\
\text { class }\end{array}$ & Season & Precipitation & $\begin{array}{c}\text { Moisture (cm) } \\
\text { antecedent } \\
\text { moisture }\end{array}$ \\
\hline 1 & wet & $<1.25$ & $<1.25$ \\
& dry & $<3.75$ & $<3.50$ \\
2 & wet & $<1.25$ & $>1.25$ \\
& dry & $<3.75$ & $>3.50$ \\
3 & wet & $1.25-3.75$ & $<1.25$ \\
& dry & $3.75-6.25$ & $<3.50$ \\
4 & wet & $1.25-3.75$ & $>1.25$ \\
& dry & $3.75-6.25$ & $>3.50$ \\
5 & wet & $>3.75$ & $<1.25$ \\
& dry & $>6.25$ & $<3.50$ \\
6 & wet & $>3.75$ & $>1.25$ \\
& dry & $>6.25$ & $>3.50$ \\
\hline
\end{tabular}

taken for live and dead material for all species.

Grasses, forbs, and standing dead vegetation were clipped and mulch was collected from $4 \quad 0.25$-m plots randomly located adjacent to each runoff plot prior to burning. Samples were dried at $60^{\circ} \mathrm{C}$ and weighed to determine $\mathrm{kg} /$ ha of mulch and total standing crop.

Data were analyzed using the Statistical Analysis System (SAS) programs (Helwig 1978, Helwig and Council 1979). Skewness and kurtosis tests were applied to runoff and sediment data to assess closeness to a normal distribution (Snedecor and Cochran 1971). Sediment values were highly skewed requiring $\log _{10}$ transformation of the data set. Analysis of variance procedures were used in testing for differences between burned and unburned plots, and means were separated using Duncan's new multiple range test $(P \leq 0.10)$ (Steele and Torrie 1980).

\section{Results and Discussion}

\section{Burning Treatments}

Effectiveness of the burning treatments was greatly influenced by moisture availability in 1980 and 1981 . Droughty conditions prevailed in 1980 . Only $72.7 \mathrm{~cm}$ of rainfall was recorded for the study area, which was $25.3 \mathrm{~cm}$ below normal. The fine fuel loads measured for the December 1980 burn for the brush and grass plots were $3,079 \mathrm{~kg} / \mathrm{ha}$ and $1,524 \mathrm{~kg} / \mathrm{ha}$, respectively. Samples of fuel collected included all material above mineral soil; a considerable portion was mulch. This had the tendency to inflate the combustible fine fuel load estimation. Burns conducted in 1980/1981 especially on the grass plots had to be spot fired because of the inability of the sparse fuel to carry the fire. The brush plots burned somewhat better but, in general, the burns were patchy and incomplete.

The study site received $122 \mathrm{~cm}$ of rainfall during 1981 . Fine fuel was not measured for the December 1981 burn; however, for the spring burn in March 1982 estimated fine fuel load for the brush and grass dominated communities were $3265 \mathrm{~kg} / \mathrm{ha}$ and 2412 $\mathrm{kg} / \mathrm{ha}$, respectively. Fine fuel load on the brush dominated community differed little from 1980/1981 estimates, but the fine fuel on the grass dominated community had increased markedly.

\section{Vegetation}

Foliar cover of live forbs or grasses on the grass dominated community was similar among treatments (Table 2). Cover of standing dead herbaceous material was lowest on early winter burned plots, intermediate on spring burned plots and greatest on 
Table 2. Mean basal and mean foliar cover $(\%)$ of herbaceous and woody vegetation $(<30 \mathrm{~cm})$ after implementation of prescribed burning treatments on brush-and grass-dominated communities in the Post Oak Savannah, Texas. Means are of six samples dates: 31 Jan. 1981 through 5 Aug. 1982.

\begin{tabular}{|c|c|c|c|c|c|}
\hline \multirow{2}{*}{$\begin{array}{l}\text { Community } \\
\text { and treatment }\end{array}$} & \multicolumn{5}{|c|}{ Basal cover } \\
\hline & Bare ground & Mulch & For & & Grass \\
\hline \multicolumn{6}{|l|}{ Grass } \\
\hline Fall & $50.5 a^{1}$ & $42.5 b$ & $3.0 \mathrm{~s}$ & & $1.5 \mathrm{~b}$ \\
\hline Spring & $44.3 a$ & $47.0 \mathrm{~b}$ & 3.7 & & $3.6 a$ \\
\hline Unburned & $26.3 b$ & $69.1 \mathrm{a}$ & 1.8 & & $1.3 \mathrm{~b}$ \\
\hline \multicolumn{6}{|l|}{ Brush } \\
\hline Fall & $41.2 a$ & $53.7 \mathrm{~b}$ & 1.7 & & $1.3 \mathrm{~b}$ \\
\hline Spring & $40.5 a$ & $53.8 \mathrm{~b}$ & 1.1 & & $3.5 \mathrm{a}$ \\
\hline \multirow[t]{3}{*}{ Unburned } & $17.4 \mathrm{~b}$ & $78.7 \mathrm{a}$ & 0.6 & & $1.4 \mathrm{~b}$ \\
\hline & \multicolumn{5}{|c|}{ Foliar cover } \\
\hline & Forb & Grass & $\begin{array}{l}\text { Standing } \\
\text { dead }\end{array}$ & Brush & $\begin{array}{l}\text { Total } \\
\text { cover }\end{array}$ \\
\hline \multicolumn{6}{|l|}{$\overline{\text { Grass }}$} \\
\hline Fall & $20.8 \mathrm{a}^{1}$ & $16.8 \mathrm{a}$ & $15.2 c$ & -2 & $52.8 \mathrm{c}$ \\
\hline Spring & $17.1 \mathrm{a}$ & $16.5 a$ & $38.4 \mathrm{~b}$ & - & $72.0 \mathrm{~b}$ \\
\hline Unburned & $14.1 \mathrm{a}$ & $13.6 \mathrm{a}$ & $59.0 \mathrm{a}$ & - & $86.7 a$ \\
\hline \multicolumn{6}{|l|}{ Brush } \\
\hline Fall & $10.0 \mathrm{a}$ & $18.1 \mathrm{a}$ & $13.9 b$ & $7.0 \mathrm{a}$ & $49.1 b$ \\
\hline Spring & $5.2 \mathrm{ab}$ & $20.3 a$ & $32.3 a$ & $4.3 a$ & $62.1 \mathrm{ab}$ \\
\hline Unburned & $2.4 \mathrm{~b}$ & $14.8 \mathrm{a}$ & $49.7 \mathrm{a}$ & $7.4 a$ & $74.6 \mathrm{a}$ \\
\hline
\end{tabular}

Treatment means followed by the same letter within columns and communities are not significantly different ( $P \leq 0.10)$ according to Duncan's new multile range test.

${ }^{2}$ No brush cover.

unburned plots. Total foliar cover was lowest on early winter burned plots and greatest on unburned plots; however, the total cover differences were due to standing dead materials.

Amount of bare ground exposed on early winter burned plots was similar to that on spring burned plots and both were greater than unburned plots on the grass-dominated community (Table 2). Mulch cover was greater on unburned plots than on early winter or spring burned plots. Forb basal cover was low and similar on all treatments but grass basal cover was greater on spring burned plots than on early winter or unburned plots. There was, during the study, on the grass-dominated community, a general increase in grass basal cover on the spring burned plots.

Foliar cover of vegetation on the brush-dominated community included woody plant cover $30 \mathrm{~cm}$ or less above the ground. Forb foliar cover was greater on early winter burned plots than on unburned plots (Table 2). However, forb cover on spring burned plots on the brush-dominated community was similar to early winter burned and unburned plots. Grass foliar cover was similar among treatments. Cover of standing dead material on spring burned plots was similar to that on unburned plots and greater than that on early winter burned plots.

Total foliar cover differences among treatments were not as apparent on the brush-dominated community as on the grass dominated community. Total foliar cover was less on early winter burned brush dominated plots than on unburned plots but both were similar to the spring burned plots. The foliar cover of woody vegetation was low and similar among treatments.

Percent bare ground was less and mulch cover greater on unburned plots than on burned brush-dominated plots (Table 2). Basal cover of forbs was similar among the various treatments. Grass basal cover on plots burned in the spring was greater than on unburned or early winter burned plots. These results were similar to those on spring burned plots in the grass-dominated community.

In general there was more bare ground on the grass-dominated community regardless of treatment. However, the percentage of mulch cover was generally greater on the brush-dominated community than the grass-dominated community. Grass basal cover of both communities was extremely low and similar. Forb basal cover was also extremely low in both communities; however, it tended to be slightly greater in the grass-dominated community than in the brush-dominated community.

\section{Runoff}

Mean runoff tended to be greater during the dry season than during the wet season (Table 3). This is probably in response to seasonal differences in storm intensity. Although soil moisture during the wet season is normally greater than during the dry season, storm intensity is lower, allowing for greater infiltration. Dry season storms are normally more intense and often the rainfall rate exceeds soils infiltration capacity.

Wet season runoff from unburned plots was greater than from spring burned plots but similar to early winter burned plots in the brush-dominated community. However, in the grass-dominated community runoff was greater from unburned plots than from either early winter or spring burned plots.

Runoff differences among treatments within moisture condition class increased as storm magnitude increased. Runoff from brushdominated plots during the wet season was similar for all treatments and moisture condition classes except in moisture condition class "four," where runoff was greater from unburned plots than from either the spring or early winter burned plots. Wet season runoff from spring burned grass plots was greater than from unburned or early winter burned plots for moisture condition class "one". Runoff from other moisture condition classes, however, was not significantly different among treatments. Although runoff during the wet season from brush-or grass-dominated communities was similar, there did appear to be a trend toward greater runoff from the unburned than from the burned plots.

Table 3. Mean of plots by wet (1 Nov. through 31 May) and dry (1 June through 31 Oct.) seasons for 18 month study period for runoff (mm), sediment concentration $(\mathrm{g} / \mathrm{1})$, and sediment export $(\mathrm{kg} / \mathrm{ha})$ after implementation of prescribed burning treatments on brush or grass dominated communities by season in the Post Oak Savannah, Texas.

\begin{tabular}{|c|c|c|c|c|c|c|c|}
\hline & & \multicolumn{6}{|c|}{ Treatment } \\
\hline & & \multicolumn{3}{|c|}{ Brush } & \multicolumn{3}{|c|}{ Grass } \\
\hline & & Fall & Spring & Unburned & Fall & Spring & Unburned \\
\hline Runoff & $\begin{array}{l}\text { Wet } \\
\text { Dry }\end{array}$ & $\begin{array}{l}1.29 \mathrm{a}^{\mathrm{l}} \\
2.26 \mathrm{a}\end{array}$ & $\begin{array}{l}1.34 \mathrm{~b} \\
1.95 \mathrm{a}\end{array}$ & $\begin{array}{l}1.77 \mathrm{a} \\
3.15 \mathrm{a}\end{array}$ & $\begin{array}{l}0.90 \mathrm{a} \\
1.22 \mathrm{a}\end{array}$ & $\begin{array}{l}1.08 \mathrm{~b} \\
1.74 \mathrm{a}\end{array}$ & $\begin{array}{l}2.78 \mathrm{a} \\
1.68 \mathrm{a}\end{array}$ \\
\hline Sediment Conc. & $\begin{array}{l}\text { Wet } \\
\text { Dry }\end{array}$ & $\begin{array}{l}0.14 a \\
0.22 a\end{array}$ & $\begin{array}{l}0.07 \mathrm{~b} \\
0.10 \mathrm{~b}\end{array}$ & $\begin{array}{l}0.09 \mathrm{a} \\
0.15 \mathrm{ab}\end{array}$ & $\begin{array}{l}0.09 a \\
0.10 a\end{array}$ & $\begin{array}{l}0.07 \mathrm{~b} \\
0.07 \mathrm{~b}\end{array}$ & $\begin{array}{l}0.10 \mathrm{a} \\
0.12 \mathrm{a}\end{array}$ \\
\hline Sediment Export & $\begin{array}{l}\text { Wet } \\
\text { Dry }\end{array}$ & $\begin{array}{c}5.10 \mathrm{a} \\
13.86 \mathrm{a}\end{array}$ & $\begin{array}{l}2.43 a \\
6.43 a\end{array}$ & $\begin{array}{r}5.86 \mathrm{a} \\
11.20 \mathrm{a}\end{array}$ & $\begin{array}{l}5.22 \mathrm{a} \\
3.80 \mathrm{a}\end{array}$ & $\begin{array}{l}3.55 \mathrm{a} \\
3.45 \mathrm{a}\end{array}$ & $\begin{array}{l}5.46 a \\
7.86 a\end{array}$ \\
\hline
\end{tabular}

'Treatment means within communities and season followed by the same letter are not significantly different ( $P \leq 0.10)$ according to Duncan's new multiple range test. 

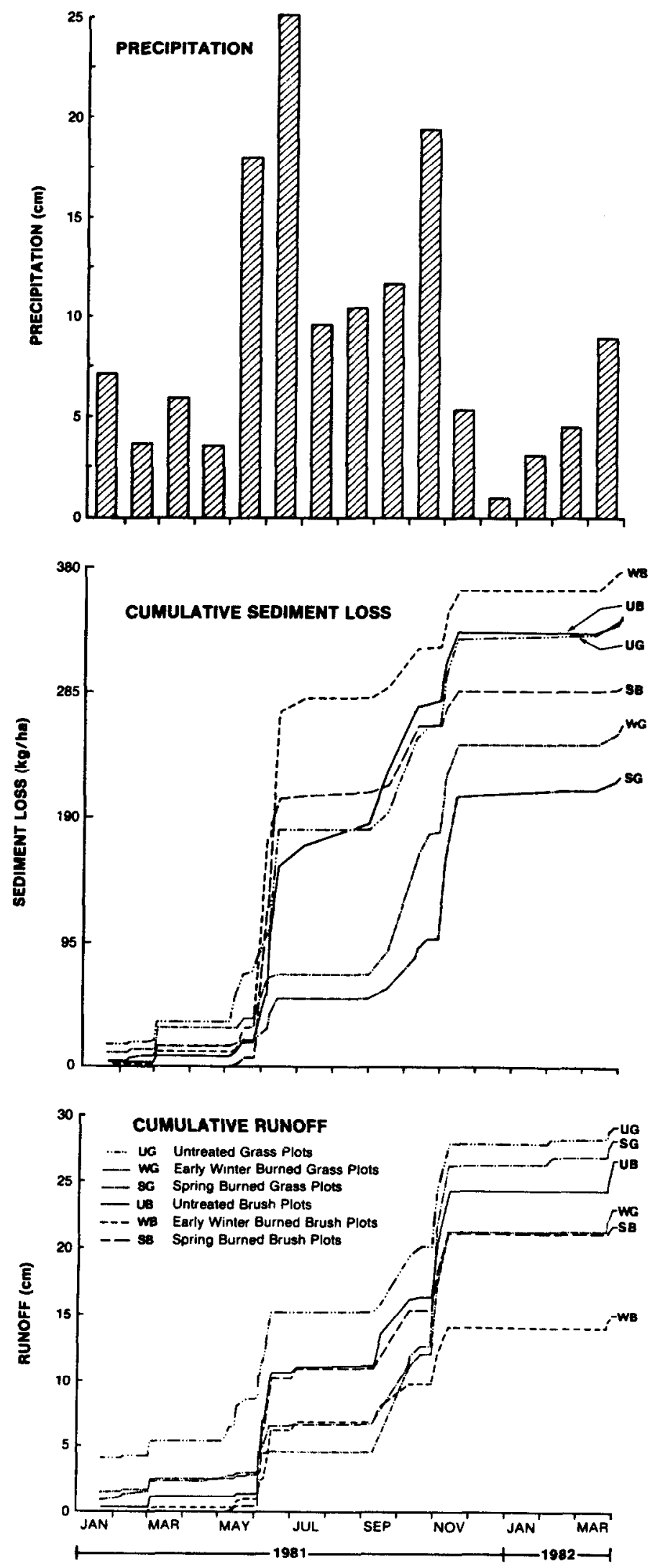

Fig. 1. Cumulative sediment loss, runoff and monthly precipitation after implementation of prescribed burning treatment on brush-and grassdominated communities in the Post Oak Savannah, Texas.
Differences among treatments or within moisture condition classes were not apparent during the dry season. Runoff from grass-dominated plots was similar, regardless of treatment or moisture condition class. The greater amounts of runoff from unburned plots, which occurred during the wet season, was not apparent during the dry season.

Cumulative runoff after 15 months ranged from $15.1 \mathrm{~cm}$ to 29.2 cm and occurred mostly during the months of March, June, September, and November (Fig. 1); however, there were no significant differences between treatments or community $(P \leq 0.05)$. There was a nonsignificant trend for runoff to be greater from the grassdominated community than from the brush-dominated community, and from unburned plots than from burned plots.

\section{Sediment}

Wet season mean sediment concentrations were similar to concentrations during the dry season for both communities (Table 3). Sediment concentrations from the grass-dominated community were less from spring burned plots than from early winter burned or unburned plots for the wet and dry season. However, in the brush-dominated community sediment concentrations from the spring burned plots were less than from early winter burned plots but similar to unburned plots for both wet and dry seasons.

Sediment concentrations varied little within moisture condition class. However, there appears to be an inverse relationship between sediment concentration and moisture condition class. As the moisture condition class increased, sediment concentration decreased. This was due to greater stormflow occurring at the higher moisture condition classes, causing a dilution in sediment concentration but did not reduce total sediment export. DeHaven et al. (1981) reported similar results from small watersheds in East Texas.

Mean sediment export from the various treatments was similar. Season did appear to affect the amount of soil lost from the plots. Sediment export during the dry season was greater than during the wet season. This suggests that soil stability was affected by its moisture content and the higher intensity storms that occurred during the dry season. The stability of the soil particles seemed to be improved when wet, decreasing the erosive effect of raindrop impact and overland flow. Dry soils, which tended to crumble and crack, were less able to resist breakdown by raindrop impact and surface runoff.

Although cumulative sediment loss during the 15-month study was almost twice as great from early winter burned brush plots than from spring burned grass plots, there was no significant difference $(P<0.05)$ in cumulative sediment loss between communities or treatments (Fig. 1). There was, however, a nonsignificant trend for greater soil loss to occur from unburned or from brushdominated plots than from burned or grass-dominated plots. Nevertheless, more soil was lost from the early winter burned brush plots $(380 \mathrm{~kg} / \mathrm{ha} / 15 \mathrm{mo}$ ) than from the other treatments (Fig. 1). This soil loss was extremely low and well below Soil Conservation Service (1978) tolerable loss for the Tabor Soil Series (11.3 metric tons/ha/yr).

Runoff, erosion, or vegetation were not adversely impacted by burning; in fact, burning tended to increase live vegetation cover, and decrease runoff and erosion. This study supports previous data (Moehring et al. 1966, Stone 1973, Pritchett 1977, Knight et al. 1983) that suggest properly prescribed burning can be an effective and efficient means of improving, modifying, or manipulating rangeland.

\section{Literature Cited}

Blackburn, W.H. 1975. Factors influencing infiltration and sediment production of semiarid rangelands in Nevada. Water Resour. Res. 11:929-937.

Brady, N.C. 1974. The Nature and Properties of Soils. 8th Ed. Macmillan Publishing Co., New York.

DeHaven, M.G., W.H. Blackburn, R.W. Knight, and A.T. Weichert. 1982. Assessment of stormflow and water quality from undisturbed and site prepared land in East Texas. Tech. Rep. 117. Texas Water Resources Institute, Texas A\&M Univ., College Station. 
Gould, F.W. 1975. Texas plants: A checklist and ecological summary. Texas Agr. Exp. Sta. No. MP-585/Revised, College Station.

Griffiths, J.F., and R.F. Strauss. 1981. The climate of Bryan-College Station, Texas. Office of the State Climatologist, Dep. Meteorol., Texas A\&M Univ., College Station.

Helwig, J.T. 1978. SAS introductory guide. SAS Institute, Inc. Raleigh, N.C.

Helwig, J.T., and K.A. Council (eds). 1979. SAS user's guide. SAS Institute, Inc., Raleigh, N.C.

Knight, R.W., W.H. Blackburn, and C.J. Scifres. 1983. Infiltration rates and sediment production following herbicide/fire brush treatments. J. Range Manage. 36:154-157.

McMurphy, W.E., and K.L. Anderson. 1965. Burning Flint Hills range. J. Kange Manage. 18:265-269.

Moehring, D.M., C.S. Grano, and J.R. Basset. 1966. Properties of forested loess soils after repeated prescribed burns. USDA Forest Serv. Res. Note SO-40. Southern Forest Exp. Sta., New Orleans, La.

Mueller-Donbois, D., and H. Ellenberg. 1974. Aims and Methods of Vegetation Ecology. John Wiley and Sons, New York, N.Y.

Osborn, B. 1954. Effectiveness of cover in reducing soil splash by raindrop impact. J. Soil Water Conserv. 9:70-76.

Pritchett, W.L. 1977. Considerations in use of fire by prescription for managing soil and water, p. 33-35. In: Proc. Fire by Prescription Symp. (Oct. 13-15, 1976, Atlanta, Ga). USDA Forest Serv.
Sauer, C.0. 1950. Grassland climax, fire and man. J. Range Manage. 3:16-21.

Scifres, C.J. 1980. Brush Management: Principles and Practices for Texas and the Southwest. Texas A\&M Univ. Press, College Station.

Shantz, H.L. 1947. The use of fire as a tool in the management of the brush ranges of California. California Div. Forestry, January.

Snedecor, G.W., and W.G. Cochran. 1971. Statistical Methods. Iowa State Univ. Press, Ames.

Soil Conservation Service. 1964. National Engineering Handbook. Hydrology, Section 4, Part I, Watershed Planning. USDA Soil Conserv. Serv.

Soil Conservation Service. 1978. Erosion handbook, water and wind, Notice Number 1. USDA Soil Conserv. Serv., Temple, Texas.

Spurr, S.H., and B.V. Barnes. 1973. Forest Ecology. The Ronald Press, New York, N.Y.

Steele, R.G.D., and J.H. Torrie. 1980. Principles and Procedures of Statistics. McGraw-Hill Book Co., Inc., New York, N.Y.

Stoddart, L.A., A.D. Smith, and T.W. Box. 1975. Range Management. 3rd. ed. McGraw-Hill Book Company, Inc., New York, N.Y.

Stone, E. 1973. The impact of timber harvest on soils and water. p. 426-467. In: Rep. Presidents Advisory Panel on Timber and Environment, Append. $\mathrm{M}$.

Trilca, M.J., and J.L.Schuster. 1969. Effects of fire on grasses of the Texas High Plains. J. Range Manage. 22:329-333.

Wright, H.A. 1974. Range burning. J. Range Manage. 27:5-11. 